\title{
Mechanisms of the immunosuppressive effects of mouse adipose tissue-derived mesenchymal stromal cells on mouse alloreactively stimulated spleen cells
}

\author{
RYO NAGAYA $^{1}$, MASAKO MIZUNO-KAMIYA ${ }^{2}$, EIJI TAKAYAMA ${ }^{2}$, HARUMI KAWAKI $^{2}$, IPPEI ONOE ${ }^{1}$, \\ TOSHIICHIRO TANABE ${ }^{1}$, KUNITERU NAGAHARA ${ }^{1}$ and NOBUO KONDOH ${ }^{2}$ \\ Departments of ${ }^{1}$ Oral Implantology and ${ }^{2}$ Oral Biochemistry, Asahi University School of Dentistry, \\ Mizuho-shi, Gifu 501-0296, Japan
}

Received September 6, 2013; Accepted October 18, 2013

DOI: $10.3892 /$ etm.2013.1382

\begin{abstract}
The mechanisms of immunomodulation by mesenchymal stromal cells remain poorly understood. In this study, the effects of mouse adipose tissue-derived mesenchymal stromal cells (ASCs) on mouse spleen cells alloreactively stimulated by anti-CD3 and anti-CD28 antibody-coated (antiCD3/CD28) beads were observed. Production of interferon- $\gamma$ by the anti-CD3/CD28 bead-stimulated spleen cells was significantly suppressed in co-culture with ASCs. However, an augmented intensity of CD69 on the stimulated spleen cells was not suppressed in the presence of ASCs. The immunosuppressive effects of ASCs were partially mediated by one or more soluble factors (26\% suppression). However, the ASCs require cell-cell contact in order to maximally exert suppression (88\%). The suppressive effect of ASCs mediated by direct cell contact was partially reversed following knockdown of $\beta 2$ microglobulin, a component of the major histocompatibility complex (MHC) class I molecule, with siRNA. The results of the study demonstrated that ASCs have significant immune modulatory effects on alloreactively stimulated spleen cells. The effects of ASCs on spleen cells are dependent on soluble factor(s) and cell contact, which is mediated by the MHC class I complex on ASCs.
\end{abstract}

\section{Introduction}

Mesenchymal stromal cells (MSCs) are originally isolated from bone marrow (BM) (1). MSCs show proliferation without the loss of undifferentiated phenotype and retain the ability to differentiate into several mesenchymal lineages, such as

Correspondence to: Dr Masako Mizuno-Kamiya, Department of Oral Biochemistry, Asahi University School of Dentistry, Mizuho-shi, Hozumi 1851, Gifu 501-0296, Japan

E-mail: mkamiya@dent.asahi-u.ac.jp

Key words: immunosuppression, adipose tissue-derived stromal cells, $\beta 2$ microglobulin, interferon- $\gamma$ bone, cartilage, adipose and muscle tissues (2). In addition to BM, MSCs have also been isolated from adipose tissue (3), placenta (4), amniotic fluid (5) and fetal tissues (6). The percentage of MSCs in BM is low (0.001-0.01\% of the mononuclear cell fraction). By contrast, adipose tissue contains a $\sim 500$-fold percentage of MSCs than BM and the process of tissue collection is simple (7).

An important characteristic of MSCs is their immunomodulatory capacity. MSCs suppress the proliferation of T cells upon allogeneic (8-19) or mitogenic stimulation (11), promote apoptosis of activated T cells (12) and enhance the generation of regulatory T cells (13). MSCs also inhibit the proliferation of B cells and natural killer cells $(14,15)$. Several factors have been implicated in the immunomodulatory effects of MSCs, including prostaglandin E2 $\left(\mathrm{PGE}_{2}\right)$, transforming growth factor- $\beta 1$ (TGF- $\beta 1$ ) and indoleamine 2,3-dioxygenase (IDO) $(15,16)$. In experimental models, administration of MSCs resulted in the prevention of graft-versus-host disease (GvHD) (17) in prolonged skin graft survival (18). The use of MSCs as a cellular therapy has been examined in clinical trials to treat GvHD (19) and Crohn's disease (20). MSCs express intermediate levels of major histocompatibility complex (MHC) class I molecules and very low levels of class II (21), which may be recognized by alloreactive T cells. Notably, the immunomodulatory capacity of adipose tissue-derived mesenchymal stromal cells (ASCs) is higher than that of BM-derived MSCs (22).

In the present study, the direct and indirect effects of ASCs on alloreactively stimulated mouse spleen cells were observed. In addition, the interferon- $\gamma$ (IFN- $\gamma$ )-producing capability of the spleen cells, the population of activated CD $69^{+}$cells among CD $45^{+}$leukocytes and the functions of MHC molecules on ASCs were investigated.

\section{Materials and methods}

Experimental animals. Thirty male BALB/c mice were purchased from Chubu Kagaku Shizai Co., Ltd. (Nagoya, Japan) and had access to Oriental MF solid chow (Oriental Yeast Co., Tokyo, Japan) and water ad libitum. This study was approved by the Animal Ethics Committee of Asahi University (Gifu, Japan; grant no. 07-016). 
Harvest and primary culture of ASCs. Four-week-old male BALB/c mice (weight, 15-20g) were sacrificed by cervical dislocation. The inguinal fat pads were harvested and washed with phosphate-buffered saline (PBS). They were excised, finely minced and then digested with $0.1 \%$ collagenase (Wako Pure Chemical Industries, Ltd., Osaka, Japan) for $40 \mathrm{~min}$ at $37^{\circ} \mathrm{C}$. After digestion, they were filtered through a cell strainer (BD Biosciences, San Jose, CA, USA). An equal volume of starting medium (FM-start ${ }^{\mathrm{TM}}$; Toyobo Co., Ltd., Osaka, Japan) was added to the cell suspension, which was then centrifuged at $270 \mathrm{x}$ g for $5 \mathrm{~min}$. Cells were resuspended with $10 \mathrm{ml}$ starting medium, plated on $100-\mathrm{mm}$ tissue culture plates and then incubated at $37^{\circ} \mathrm{C}$ in $5 \% \mathrm{CO}_{2}$. The medium was replaced every 3 days and the non-adherent cells were discarded. The cells were harvested at $80-90 \%$ confluence with $0.25 \%$ trypsin $/ 0.1 \%$ ethylenediaminetetraacetic acid (EDTA; Invitrogen Life Technologies, Grand Island, NY, USA), collected by centrifugation at $190 \mathrm{x}$ g for $5 \mathrm{~min}$ at room temperature, then passaged at a ratio of $1: 3$. The cells were cultured in FM-medium ${ }^{\mathrm{TM}}$ (Toyobo Co., Ltd.) at $37^{\circ} \mathrm{C}$, $5 \% \mathrm{CO}_{2}$. Of the cultured ASCs, passage 3 were used in this study.

Phenotype and differentiation capacity of ASCs. The capacity of ASCs to differentiate along adipogenic and osteogenic lineages was assessed as previously described (23). Briefly, for adipogenic differentiation, cells were induced by adding 1-methyl-3-isobutylxanthine $(0.5 \mathrm{mM})$, insulin $(10 \mu \mathrm{M})$, indomethacin $(200 \mu \mathrm{M})$ and dexamethasone $(1 \mu \mathrm{M})$ to Dulbecco's modified Eagle's medium (DMEM; Wako Pure Chemical Industries, Ltd.), containing 10\% fetal bovine serum (FBS; Invitrogen) and 1\% antibiotic antimycotic solution (10,000 U/ml penicillin, $10,000 \mu \mathrm{g} / \mathrm{ml}$ streptomycin and $25 \mu \mathrm{g} /$ $\mathrm{ml}$ amphotericin B; Gibco-BRL). This medium was replaced every 3-4 days for 2 weeks. Adipogenesis was measured by the accumulation of neutral lipids in fat vacuoles, observed using Oil red O staining.

For osteogenic differentiation, cells were grown in minimum essential medium- $\alpha$ (MEM- $\alpha$; Wako Pure Chemical Industries, Ltd.,) supplemented with ascorbic acid $(50 \mu \mathrm{g} / \mathrm{ml})$ and glycerophosphate $(10 \mathrm{mM})$ containing $10 \% \mathrm{FBS}(\mathrm{JRH}$ Biosciences, Lenexa, KS, USA) and 1\% Pen Strep (penicillin, $10,000 \mathrm{U} / \mathrm{ml}$ and streptomycin, 10,000 $\mu \mathrm{g} / \mathrm{ml}$; Gibco-BRL). This medium was replaced every 3-4 days for 3 weeks. Differentiated cells were examined by Alizarin red (Wako Pure Chemical Industries, Ltd.) staining.

Preparation of mouse spleen cells. Twenty-four-week-old male $\mathrm{BALB} / \mathrm{c}$ mice were sacrificed by cervical dislocation. The spleen was removed. Spleen cells were isolated by smashing the tissue with stainless steel mesh in RPMI-1640 medium (SigmaAldrich, St. Louis, MO, USA) containing 10\% FBS (Biowest SAS, Nuaillé, France), $50 \mu \mathrm{M}$ 2-mercaptoethanol (Nacalai Tesque, Inc., Kyoto, Japan) and $1 \%$ antibiotic antimycotic solution (Gibco-BRL). Cells were collected by centrifugation at $430 \mathrm{x} \mathrm{g}$ for $5 \mathrm{~min}$ and then resuspended with $10 \mathrm{ml}$ red blood cell lysis buffer [10 mM Tris- $\mathrm{HCl}$ ( $\mathrm{pH}$ 7.3) containing $140 \mathrm{mM} \mathrm{NH}_{4} \mathrm{Cl}$ and $1 \mathrm{mM}$ EDTA]. After incubation for $5 \mathrm{~min}$ at room temperature, the cells were washed three times with RPMI-1640 medium and centrifuged at 1,500 rpm for $5 \mathrm{~min}$.
The spleen cells were re-suspended with RPMI-1640 medium and filtered using a cell strainer (BD Biosciences) to remove the residue.

Analysis of cytokine production by spleen cells. Spleen cells were suspended in RPMI-1640 supplemented with $10 \% \mathrm{FBS}, 50 \mu \mathrm{M}$ 2-mercaptoethanol and $1 \%$ antibiotic antimycotic solution. Cell suspension $\left(4 \times 10^{6} / \mathrm{ml}\right)$ was added $\left(0.1 \mathrm{ml} /\right.$ well, in triplicate) to a 96 -well plate, to which $4 \times 10^{5}$ of anti-CD3 and anti-CD28 antibody-coated (anti-CD3/ CD28) beads (Dynabeads ${ }^{\circledR}$ Mouse T-Activator CD3/CD28; Invitrogen Life Technologies) were added. Additionally, ASCs (0-16,000 cells/well) were added to the wells. To examine the indirect effects of ASCs on the stimulated spleen cells, Transwell chambers (pore size, $0.4 \mu \mathrm{m}$; Corning Inc., Corning, NY, USA) 24-well plates were used. The spleen cell suspension together with anti-CD3/CD28 beads were transferred to the upper chambers and ASCs were added to the bottom chambers of a Transwell.

The cells were incubated for $48 \mathrm{~h}$ in $5 \% \mathrm{CO}_{2}$ at $37^{\circ} \mathrm{C}$, and then the supernatant was harvested by centrifugation at $1,710 \mathrm{x} \mathrm{g}$ for $5 \mathrm{~min}$ and stored at $-80^{\circ} \mathrm{C}$. Production of IFN- $\gamma$ in the supernatant of cell culture was assayed by enzyme-linked immunosorbent assay using BD OptE1A Set Mouse IFN- $\gamma$ (BD Biosciences).

Flow cytometry. A four-colored panel was used to analyze the stimulated spleen cells. The spleen cells were harvested from the culture and transferred to a Falcon tube by thorough resuspension with a pipette. The cells were washed twice with PBS and stained with anti-mouse antibodies (mAbs), including phycoerythrin (PE)-conjugated $\mathrm{mAb}$ specific for $\mathrm{CD} 4$ (clone GK1.5), peridinin chlorophyll-a protein-cyanine 5.5 (PerCP-Cy ${ }^{\mathrm{TM}}$ 5.5)-conjugated $\mathrm{mAb}$ specific for CD45 (clone 104) and allophycocyanin (APC)-conjugated mAb specific for CD69 (clone H1.2F3; eBioscience, San Diego, CA, USA). Fluorescein isothiocyanate (FITC)-conjugated $\mathrm{mAb}$ specific for CD8 (KT15) was purchased from Immunotech (Marseille, France). Cells were re-suspended in PBS containing 2\% FBS, $1 \mathrm{mM}$ EDTA and 1\% sodium azide, then analyzed by flow cytometry (FACSCalibur; BD Bioscience) with Cell Quest software (BD Bioscience).

Knockdown of $\beta 2$-microglobulin $(\beta 2 M)$ in ASCs. $\beta 2 \mathrm{M}$ siRNA duplex (Silencer ${ }^{\circledR}$ select Pre-designed siRNA; Ambion, Invitrogen Life Technologies) was used to knockdown the representative gene in ASCs. Sense and antisense sequences of $\beta 2 \mathrm{M}$ siRNA duplex were: 5'-gcc uca cau uga aau cca att-3' and 5'-uug gau uuc aau gug agg cgg-3'. Briefly, ASCs $\left(1 \times 10^{4}\right)$ were seeded in a 96-well plate with $0.1 \mathrm{ml}$ Opti-MEM (Invitrogen Life Technologies). Then, 6 pmol siRNA and $1 \mu \mathrm{l}$ Lipofectamine (Invitrogen Life Technologies) were added. Cells with reagents were incubated for $20 \mathrm{~min}$ in $5 \% \mathrm{CO}_{2}$ at $37^{\circ} \mathrm{C}$, then $10 \mu \mathrm{l} \mathrm{FBS}$ was added. The mixture was incubated for $4 \mathrm{~h}$, and then the medium was replaced with DMEM containing 10\% FBS. After 48 h, transfected ASCs were used for further experiments.

Quantitative polymerase chain reaction ( $q P C R)$. Knockdown of endogenous $\beta 2 \mathrm{M}$ in ASCs was confirmed by semi-qPCR. 

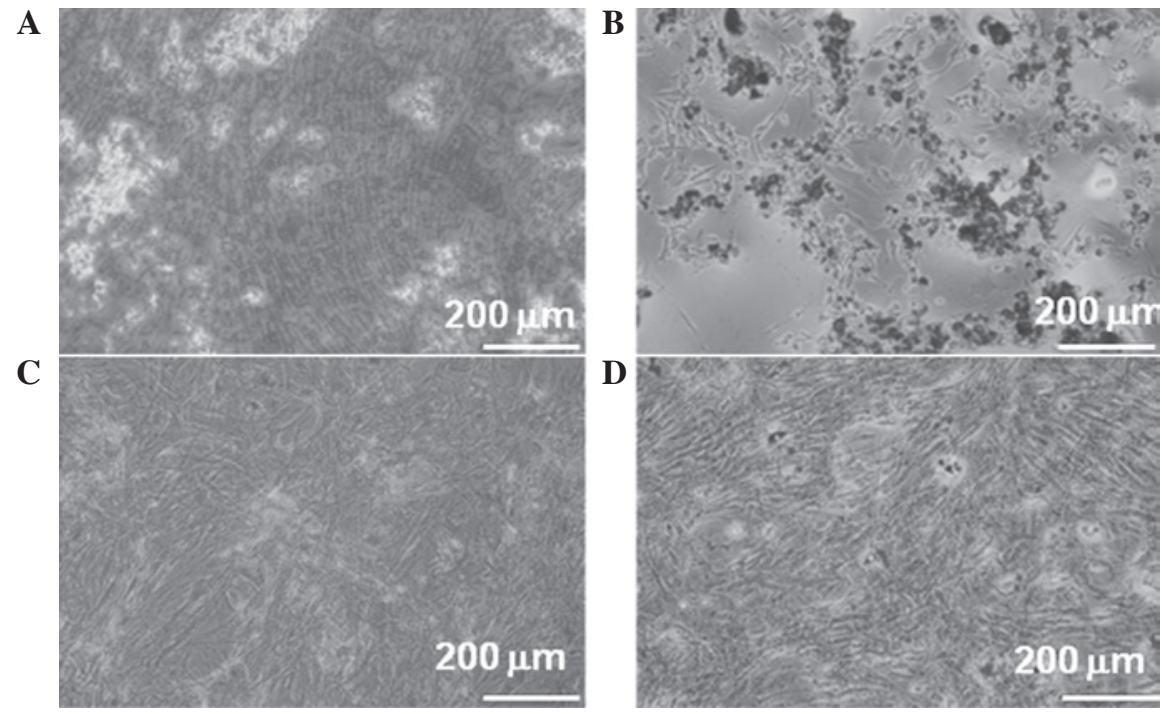

Figure 1. Differentiation of ASCs. ASCs were observed to differentiate toward (A) osteoblasts or (B) adipocytes in each inductive culture media following Alizarin red (A and C) and Oil Red O (B and D) staining. (C and D) No changes were observed in the cells that were not treated with inductive culture medium. ASCs, adipose tissue-derived mesenchymal stromal cells.

The whole-cell RNA extraction and semi-qPCR technique were conducted as previously described (24). Primer sequences were as follows: $\beta 2 \mathrm{M}$, forward 5 '-gca ggc gta tgt atc agt ctc agt-3' and reverse $5^{\prime}$-gag aat ggg aag ccg aac ata ct-3'; ribosomal protein S5 (RPS5), forward 5'-aga aga ctc aac acg cat tgg gc-3' and reverse 5'-gca ctc agc gat ggt ctt gat gt-3'. The expression levels of $\beta 2 \mathrm{M}$ mRNA were normalized as a ratio to that of RPS5-mRNA.

Statistics. Data are expressed as mean \pm standard deviation. Student's t-test was applied to determine the significance of differences between two groups. $\mathrm{P}<0.05$ was considered to indicate a statistically significant difference.

\section{Results}

In vitro differentiation of ASCs. ASCs were tested for their capacity to differentiate toward the osteogenic and adipogenic lineages. The cells treated with osteogenic medium underwent a morphological change demonstrating calcium deposition (Fig. 1A). In the adipogenic medium, the cells may have been induced toward adipogenic differentiation as shown by the accumulation of lipid vacuoles (Fig. 1B). However, no apparent changes were observed in untreated ASCs (Fig. 1C and D).

These results demonstrated that most of the cells harbor characteristic phenotypes of ASCs to differentiate along adipogenic and osteogenic lineages.

Effects of ASCs on alloreactively stimulated spleen cells. It has been identified that MSCs mainly control the Th1 response (25). Among the acute inflammatory molecules, the current study focused on IFN- $\gamma$, as this cytokine is a major product of Th1 cells, which reduces the Th2 phenotype and stimulates several key functions to activate macrophages and anti-tumor reaction (26). Our preliminary experiments revealed that the production of IFN- $\gamma$ by the anti-CD3/CD28 bead-stimulated spleen cells was significantly upregulated by $48 \mathrm{~h}$ and the elevated levels continued until $96 \mathrm{~h}$ (data not shown). Therefore, spleen cells $\left(4 \times 10^{5}\right)$ and anti-CD3/CD28 beads (Invitrogen Life Technologies) were co-cultured with ASCs $(0-16,000$ cells/well) for $48 \mathrm{~h}$ (Fig. 2A). As shown in Fig. $2 \mathrm{~A}$, the production of IFN- $\gamma$ was markedly suppressed by the ASCs in a dose-dependent manner. ASCs $(n=8,000)$ showed maximal suppression and the suppressive level was unchanged up to 16,000 ASCs.

In addition to the direct co-culture assay, Transwell assays were performed to determine whether cell-to-cell contact was necessary for the suppression of activated spleen cells by ASCs (Fig. 2B). ASCs were plated in the lower wells; Transwell inserts containing the anti-CD3/CD28 beads and spleen cells were placed over each well. After $48 \mathrm{~h}$, the volume of secreted IFN $-\gamma$ was reduced to $74.4 \pm 19.4 \%$ of control (without ASCs; $\mathrm{P}<0.05$ ) in contactless Transwell culture (Fig. 2Ba). However, the concentration of secreted IFN- $\gamma$ was markedly reduced to $11.8 \pm 0.3 \%(\mathrm{P}<0.01)$ in the direct co-culture (Fig. $2 \mathrm{Bb})$.

The results revealed that ASCs require direct cell-to-cell contact to maximally suppress IFN- $\gamma$ production by activated spleen cells. However, even in the absence of cell contact, ASCs partially suppressed the IFN- $\gamma$ production via one or more secreted factors.

CD69 $9^{+}$activated spleen $T$ cells in the presence and absence of ASCs. To investigate whether the activation status of T cells is changed by ASCs or not, the expression of CD69 on stimulated spleen cells was analyzed by flow cytometry (Fig. 3). CD69 is the earliest inducible cell surface glycoprotein acquired during lymphoid activation, which is involved in lymphocyte proliferation and function (27). In order to select all leukocytes, CD45 cells were first gated (100\%). CD69 positive/negative fractions among $\mathrm{CD}^{+} / \mathrm{CD} 8^{-}$and $\mathrm{CD} 4^{-} / \mathrm{CD} 8^{+} \mathrm{T}$ subsets were compared. The results are summarized in Fig. 3. No CD69+ cells were detected in $\mathrm{CD} 45^{+}$un-stimulated spleen cells. Following stimulation with the anti-CD3/CD28 beads, $\mathrm{CD}^{+} 9^{+}$populations emerged in the $\mathrm{CD} 4^{+} / \mathrm{CD} 8^{-}$and $\mathrm{CD} 4 / \mathrm{CD}^{+} \mathrm{T}$ subsets, as $7.6 \%$ and $5.5 \%$, respectively. In the presence of ASCs, the 
$\mathbf{A}$

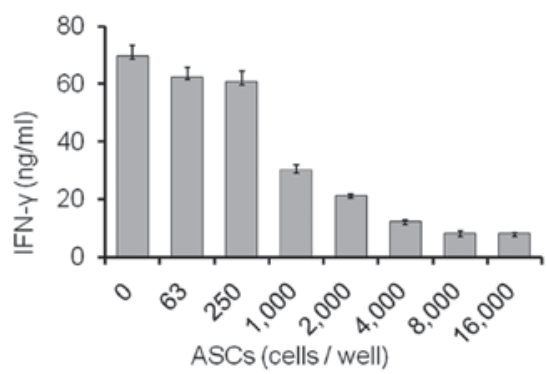

B

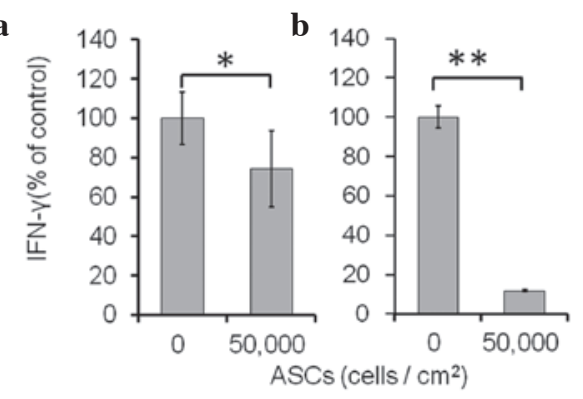

Figure 2. (A) Immunosuppressive effects of ASCs on alloreactively stimulated spleen cells. In each well, the indicated numbers of ASCs were mixed with $4 \times 10^{5}$ spleen cells and $4 \times 10^{5} \mathrm{CD} 3 / \mathrm{CD} 28$ beads. (B) Indirect (a) and direct (b) effects of ASCs on anti-CD3/CD28 bead-stimulated spleen cells were examined using Transwell chambers. (a) Spleen cells $\left(4 \times 10^{5}\right)$ were seeded with anti-CD3/CD28 beads in the upper chamber in the presence (right column) or absence (left column) of $1.6 \times 10^{5}$ ASCs seeded in the lower chamber. (b) The same number of spleen cells were seeded with anti-CD3/CD28 beads in the presence (right column) or absence (left column) of ASCs in the lower chambers. Production of IFN- $\gamma$ in the supernatant $(\mathrm{ng} / \mathrm{ml})$ is indicated by the ordinate. Experiments were repeated in triplicates and results are described as the means \pm standard deviation. The Student's t-test was used to test the probability of significant differences between samples. ${ }^{*} \mathrm{P}<0.05$ and ${ }^{* *} \mathrm{P}<0.01$. ASCs, adipose tissue-derived mesenchymal stromal cells; IFN- $\gamma$, interferon- $\gamma$.

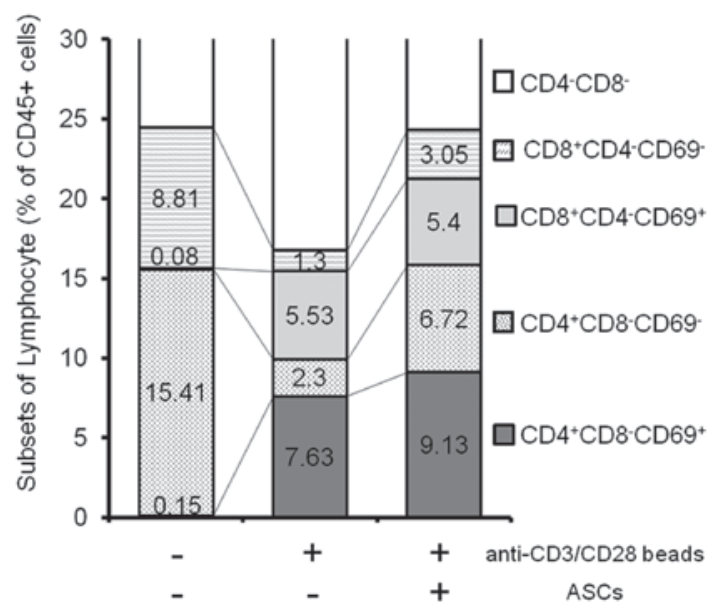

Figure 3. Flow cytometric analysis of T-cell subsets in $\mathrm{CD}_{4} 5^{+}$spleen cells. Spleen cells $\left(4 \times 10^{5}\right)$ were cultured in the presence or absence of $4 \times 10^{5}$ anti-CD3/CD28 beads and ASCs for $12 \mathrm{~h}$. The cells were harvested, then FACS analyses were performed using anti-CD45 (PerCP-Cy ${ }^{\mathrm{TM}} 5.5$ ), anti-CD4 (PE), anti-CD8 (FITC) and anti-CD69 (APC) antibodies. The percentage of each cell subpopulation (denoted on the right side) among the $\mathrm{CD} 45^{+}$total lymphocytes are indicated. ASCs, adipose tissue-derived mesenchymal stromal cells.

production of IFN- $\gamma$ was greatly suppressed; however, certain populations of $\mathrm{CD}^{-} 9^{+}$continued to exist in the $\mathrm{CD} 4^{+} / \mathrm{CD} 8$ and $\mathrm{CD} 4 / \mathrm{CD}^{+}$subsets, as $9.1 \%$ and $5.4 \%$, respectively.
A

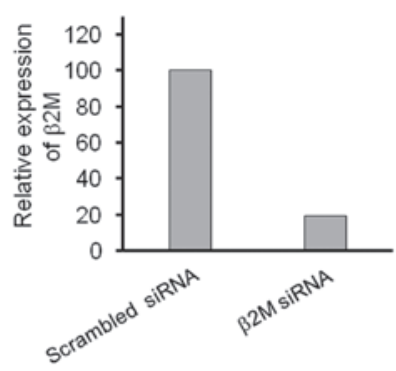

B

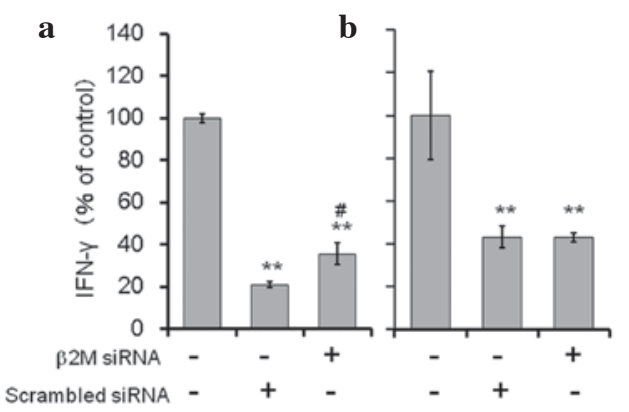

Figure 4. (A) Suppression of endogenous $\beta 2 \mathrm{M}$ transcripts in ASCs transfected with $\beta 2 \mathrm{M}$-specific siRNA. The expression of endogenous $\beta 2 \mathrm{M}$ mRNA in siRNA-transfected ASCs was confirmed by semi-quantitative PCR. The relative expression level of $\beta 2 \mathrm{M}$ mRNA was normalized as a ratio to that of RPS5-mRNA. Results are described as a mean of duplicate experiments. (B) IFN- $\gamma$ production by stimulated spleen cells in the presence or absence of siRNA-transfected ASCs. Anti-CD3/CD28-stimulated spleen cells were directly (a), or indirectly (b) co-cultured with $\beta 2 \mathrm{M}$-specific or control (scrambled) siRNA-transfected ASCs. Relative IFN- $\gamma$ levels in the supernatant are indicated by the ordinate. Experiments were repeated twice with good reproducibility. Results from a representative experiment are summarized. Values in more than triplicates were described as the mean \pm standard deviation. The Student's t-test was used to test the probability of significant differences between samples. ${ }^{\#} \mathrm{P}<0.05 \beta 2 \mathrm{M}$ siRNA vs. scrambled siRNA; ${ }^{* *} \mathrm{P}<0.01 \beta 2 \mathrm{M}$ siRNA or scrambled siRNA vs. control (without ASCs). $\beta 2 \mathrm{M}$, $\beta 2$ microglobulin; ASCs, adipose tissue-derived mesenchymal stromal cells; RPS5, ribosomal protein S5; IFN- $\gamma$, interferon- $\gamma$.

These results suggested that the suppressive effects of ASCs on the activated spleen cells did not interfere with the signaling loop mediated by $\mathrm{T}$ cell receptors.

Role of MHC class I molecules on the immunosuppressive function of ASCs. It has been identified that the immunosuppressive effects of MSCs involve a nonclassical MHC, HLA-G $(28,29)$. HLA-G is expressed in membrane-bound and soluble isoforms (29). In order to examine the association of MHC molecules and the suppressive effects of mouse ASCs, knockdown of endogenous $\beta 2 \mathrm{M}$ in ASCs was performed, as the molecule is a component of MHC class I molecules, and also necessary for cell surface expression of MHC class I molecules and stability (30). As shown in Fig. 4A, $\beta 2 \mathrm{M}$ siRNA-transfected ASCs expressed a lower level of endogenous $\beta 2 \mathrm{M}$ mRNA $(<20 \%)$ compared with that of the non-specific scrambled RNA-transfected cells.

In the direct co-culture of the anti-CD3/CD28-stimulated spleen cells and non-specific scrambled RNA-transfected ASCs, the level of IFN- $\gamma$ production was considerably reduced (to $21 \%$ of the control). By contrast, IFN- $\gamma$ production was significantly recovered (to $36 \%$ of the control) in the co-culture using $\beta 2 \mathrm{M}$ siRNA transfectants. Furthermore, in the contactless co-culture using a Transwell, the level of IFN- $\gamma$ produced 
by the spleen cells was unchanged between those treated with $\beta 2 \mathrm{M}$ siRNA-transfected ACSs and those treated with control siRNA transfected ASCs.

The results suggest that the suppressive function of ASCs on spleen cells is directly mediated by an MHC class I complex.

\section{Discussion}

In the present study, it was demonstrated that mouse ASCs markedly suppressed IFN- $\gamma$ production by anti-CD3/CD28 bead-stimulated spleen cells; however, certain populations of $\mathrm{CD} 9^{+}$existed in $\mathrm{CD}^{+} / \mathrm{CD}^{-}$and $\mathrm{CD} 4^{-} / \mathrm{CD}^{+}$subsets, even in the presence of ASCs. This observation is similar to that previously reported for a co-culture with BM-derived MSCs, where proliferation was significantly reduced, while the expression of activation markers, CD25 and CD69, was unchanged in anti-CD3/CD28-stimulated $\mathrm{T}$ cells (31). These results suggest that the suppressive effects of ASCs on the activated spleen cells did not interfere with the signaling loop mediated by $\mathrm{T}$ cell receptors.

The results of the Transwell assay in the present study demonstrated that in the absence of cell contact, ASCs partially suppressed IFN- $\gamma$ production, possibly via one or more secreted products. Several factors have been implicated in the immunomodulatory effects of MSCs, including $\mathrm{PGE}_{2}$, TGF- $\beta 1$, IDO $(15,16)$ and nitric oxide (NO) (30). However, in the present study, the results obtained with the Transwell system demonstrated that ASCs require direct cell-to-cell contact to maximally suppress the activated spleen cells.

NO is known as one of the major mediators of T-cell suppression. T-cell-MSC contact is also critical for the efficient production of NO from MSCs (31), suggesting a dynamic cross talk, including direct cell-cell contact between MSCs and lymphocytes, is required for these immunosuppressive effects. It has been reported that BM-derived MSCs express HLA-G protein, a non-classical HLA class I molecule, and the molecule has an immunosuppressive function by reducing lymphocyte proliferation (29). Stable expression of HLA-G1 has been shown to enhance the immunosuppressive effects of human ASCs (32). Furthermore, inhibitors of mevalonate synthesis have demonstrated the ability to downregulate the expression levels of adhesion molecules, including HLA class I, resulting in the prevention of immunosuppressive effects of BM-derived MSCs (33). Therefore, we have attempted to knockdown the endogenous expression of mouse MHC class I molecules, including H2-D1, H2-K1, H2-Ke and H2-Ke6 in mouse ASCs using siRNAs; however, the immunosuppressive effects of the ASCs were unaffected (data not shown). Following this, in the present study, the expression of endogenous $\beta 2 \mathrm{M}$ was knocked down in ASCs because this molecule is a universal component of MHC class I complexes necessary for cell surface expression and stability of MHC class I molecules (33). The results revealed that the immunosuppressive effects of ASCs on activated spleen cells were significantly, but only partially alleviated in $\beta 2 \mathrm{M}$ siRNA-transfected ASCs. In addition, in the contactless co-culture using a Transwell, the immunosuppressive effects of ASCs were unaffected regardless of the level of endogenous $\beta 2 \mathrm{M}$, which was significantly reduced by siRNA, suggesting that the effects of $\beta 2 \mathrm{M}$ are not mediated merely by soluble factors. These results suggest that one or more additional MHC class I molecules may be responsible for the immunomodulatory functions of mouse ASCs, or that a combination of a number of adhesion molecules is essential to confer the function to the cells.

In conclusion, in the direct co-culture, the suppressive function of mouse ASCs on spleen cells is partially mediated by an MHC class I complex. The results of the present study may provide a novel insight for further analysis of the immunomodulatory mechanisms in MSCs.

\section{Acknowledgements}

This study was supported by a grant from the Grant-in-Aid for Scientific Research (C) (grant no. 23592976) provided by the Ministry of Education, Culture, Sports, Science and Technology of Japan.

\section{References}

1. Friedenstein AJ, Gorskaja JF and Kulagina NN: Fibroblast precursors in normal and irradiated mouse hematopoietic organs. Exp Hematol 4: 267-274, 1976.

2. Prockop DJ: Marrow stromal cells as stem cells for nonhematopoietic tissues. Science 276: 71-74, 1997.

3. Zuk PA, Zhu M, Mizuno H, Huang J, Futrell JW, Katz AJ, Benhaim P, Lorenz HP and Hedrick MH: Multilineage cells from human adipose tissue: implications for cell-based therapies. Tissue Eng 7: 211-228, 2001.

4. In 't Anker PS, Scherjon SA, Kleijburg-van der Keur C, de Groot-Swings GM, Claas FH, Fibbe WE and Kanhai HH: Isolation of mesenchymal stem cells of fetal or maternal origin from human placenta. Stem Cells 22: 1338-1345, 2004.

5. In 't Anker PS, Scherjon SA, Kleijburg-van der Keur C, Noort WA, Claas FH, Willemze R, Fibbe WE and Kanhai HH: Amniotic fluid as a novel source of mesenchymal stem cells for therapeutic transplantation. Blood 102: 1548-1549, 2003.

6. In 't Anker PS, Noort WA, Scherjon SA, Kleijburg-van der Keur C, Kruisselbrink AB, van Bezooijen RL, Beekhuizen W, Willemze R, Kanhai HH and Fibbe WE: Mesenchymal stem cells in human second-trimester bone marrow, liver, lung, and spleen exhibit a similar immunophenotype but a heterogeneous multilineage differentiation potential. Haematologica 88 : $845-852,2003$

7. Fraser JK, Schreiber R, Strem B, Zhu M, Alfonso Z, Wulur I and Hedrick MH: Plasticity of human adipose stem cells toward endothelial cells and cardiomyocytes. Nat Clin Pract Cardiovasc Med 3 (Suppl 1): S33-S37, 2006.

8. Le Blanc K, Tammik L, Sundberg B, Haynesworth SE and Ringdén O: Mesenchymal stem cells inhibit and stimulate mixed lymphocyte cultures and mitogenic responses independently of the major histocompatibility complex. Scand J Immunol 57:11-20, 2003.

9. Potian JA, Aviv H, Ponzio NM, Harrison JS and Rameshwar P: Veto-like activity of mesenchymal stem cells: functional discrimination between cellular responses to alloantigens and recall antigens. J Immunol 171: 3426-3434, 2003.

10. Tse WT, Pendleton JD, Beyer WM, Egalka MC and Guinan EC: Suppression of allogeneic T-cell proliferation by human marrow stromal cells: implications in transplantation. Transplantation 75: 389-397, 2003.

11. Di Nicola M, Carlo-Stella C, Magni M, Milanesi M, Longoni PD, Matteucci P, Grisanti S and Gianni AM: Human bone marrow stromal cells suppress T- lymphocyte proliferation induced by cellular or nonspecific mitogenic stimuli. Blood 99: 3838-3843, 2002.

12. Plumas J, Chaperot L, Richard MJ, Molens JP, Bensa JC and Favrot MC: Mesenchymal stem cells induce apoptosis of activated T cells. Leukemia 19: 1597-1604, 2005.

13. Djouad F, Plence P, Bony C, Tropel P, Apparailly F, Sany J, Noël D and Jorgensen C: Immunosuppressive effect of mesenchymal stem cells favors tumor growth in allogeneic animals. Blood 102: 3837-3844, 2003. 
14. Corcione A, Benvenuto F, Ferretti E, Giunti D, Cappiello V, Cazzanti F, Risso M, Gualandi F, Mancardi GL, Pistoia V and Uccelli A: Human mesenchymal stem cells modulate B-cell functions. Blood 107: 367-372, 2006.

15. Spaggiari GM, Capobianco A, Abdelrazik H, Becchetti F, Mingari MC and Moretta L: Mesenchymal stem cells inhibit natural killer-cell proliferation, cytotoxicity, and cytokine production: role of indoleamine 2,3-dioxygenase and prostaglandin E2. Blood 111: 1327-1333, 2008.

16. English K, Ryan JM, Tobin L, Murphy MJ, Barry FP and Mahon BP: Cell contact, prostaglandin E(2) and transforming growth factor beta 1 play non-redundant roles in human mesenchymal stem cell induction of $\mathrm{CD} 4{ }^{+} \mathrm{CD} 25^{\text {High }}$ forkhead box $\mathrm{P} 3^{+}$ regulatory T cells. Clin Exp Immunol 156: 149-160, 2009.

17. Le Blanc K, Rasmusson I, Sundberg B, Götherström C, Hassan M, Uzunel M and Ringdén O: Treatment of severe acute graft-versus-host disease with third party haploidentical mesenchymal stem cells. Lancet 363: 1439-1441, 2004.

18. Hoogduijn MJ, Popp FC, Grohnert A, Crop MJ, van Rhijn M, Rowshani AT, Eggenhofer E, Renner P, Reinders ME, Rabelink TJ, van der Laan LJ, Dor FJ, Ijzermans JN, Genever PG, Lange C, Durrbach A, Houtgraaf JH, Christ B, Seifert M, Shagidulin M, Donckier V, Deans R, Ringden O, Perico N, Remuzzi G, Bartholomew A, Schlitt HJ, Weimar W, Baan CC and Dahlke MH; MISOT Study Group: Advancement of mesenchymal stem cell therapy in solid organ transplantation (MISOT). Transplantation 90: 124-126, 2010.

19. Le Blanc K, Frassoni F, Ball L, Locatelli F, Roelofs H, Lewis I, Lanino E, Sundberg B, Bernardo ME, Remberger M, Dini G, Egeler RM, Bacigalupo A, Fibbe W and Ringdén O; Development Committee of the Eurpoean Group for Blood and Marrow Transplantation: Mesenchymal stem cells for treatment of steroid-resistant, severe, acute graft-versus-host disease: a phase II study. Lancet 371: 1579-1586, 2008.

20. Ciccocioppo R, Bernardo ME, Sgarella A, Maccario R, Avanzini MA, Ubezio C, Minelli A, Alvisi C, Vanoli A, Calliada F, Dionigi P, Perotti C, Locatelli F and Corazza GR: Autologous bone marrow-derived mesenchymal stromal cells in the treatment of fistulising Crohn's disease. Gut 60: 788-798, 2011.

21. Tse WT, Pendleton JD, Beyer WM, Egalka MC and Guinan EC: Suppression of allogeneic T-cell proliferation by human marrow stromal cells: implications in transplantation. Transplantation 75 : 389-397, 2003

22. Melief SM, Zwaginga JJ, Fibbe WE and Roelofs H: Adipose tissue-derived multipotent stromal cells have a higher immunomodulatory capacity than their bone marrow-derived counterparts. Stem Cells Transl Med 2: 455-463, 2013.
23. Pittenger MF, Mackay AM, Beck SC, Jaiswal RK, Douglas R, Mosca JD, Moorman MA, Simonetti DW, Craig S and Marshak DR: Multilineage potential of adult human mesenchymal stem cells. Science 284: 143-147, 1999.

24. Kondoh N, Ishikawa T, Ohkura S, Arai M, Hada A, Yamazaki Y, Kitagawa Y, Shindoh M, Takahashi M, Ando T, Sato Y, Izumo T, Hitomi $\mathrm{K}$ and Yamamoto M: Gene expression signatures that classify the mode of invasion of primary oral squamous cell carcinomas. Mol Carcinog 47: 744-756, 2008

25. Lim JY, Park MJ, Im KI, Kim N, Jeon EJ, Kim EJ, Cho ML and Cho SG: Combination cell therapy using mesenchymal stem cells and regulatory $\mathrm{T}$ cells provides a synergistic immunomodulatory effect associated with reciprocal regulation of Th1/Th2 and Th17/Treg cells in a murine acute graft-versus-host disease model. Cell Transplant: Feb 26, 2013 (Epub ahead of print).

26. Schroder K, Hertzog PJ, Ravasi T and Hume DA: Interferon-gamma: an overview of signals, mechanisms and functions. J Leukoc Biol 75: 163-189, 2004.

27. Cambiaggi C, Scupoli MT, Cestari T, Gerosa F, Carra G, Tridente G and Accolla RS: Constitutive expression of CD69 in interspecies T-cell hybrids and locus assignment to human chromosome 12. Immunogenetics 36: 117-120, 1992.

28. Yang HM, Sung JH, Choi YS, Lee HJ, Roh CR, Kim J, Shin M, Song S, Kwon CH, Joh JW and Kim SJ: Enhancement of the immunosuppressive effect of human adipose tissue-derived mesenchymal stromal cells through HLA-G1 expression. Cytotherapy 14: 70-79, 2012.

29. Nasef A, Mathieu N, Chapel A, Frick J, Francois S, Mazurier C, Boutarfa A, Bouchet S, Gorin NC, Thierry D and Fouillard L: Immunosuppressive effects of mesenchymal stem cells: involvement of HLA-G. Transplantation 84: 231-237, 2007.

30. Alberts B, Johnson A, Lewis J, Raff M, Roberts K and Walter P: $\mathrm{T}$ cells and MHC proteins. In: Molecular biology of the cell. 5th edition. Garland Science, New York, NY, pp1569-1588, 2008.

31. Sato K, Ozaki K, Oh I, Meguro A, Hatanaka K, Nagai T, Muroi K and Ozawa K: Nitric oxide plays a critical role in suppression of T-cell proliferation by mesenchymal stem cells. Blood 109: 228-234, 2007

32. Yang HM, Sung JH, Choi YS, Lee HJ, Roh CR, Kim J, Shin M, Song S, Kwon CH, Joh JW and Kim SJ: Enhancement of the immunosuppressive effect of human adipose tissue-derived mesenchymal stromal cells through HLA-G1 expression. Cytotherapy 14: 70-79, 2012

33. Musso A, Zocchi MR and Poggi A: Relevance of the mevalonate biosynthetic pathway in the regulation of bone marrow mesenchymal stromal cell-mediated effects on T-cell proliferation and B-cell survival. Haematologica 96: 16-23, 2011. 